Check for updates

Cite this: RSC Adv., 2017, 7, 28994

Received 13th February 2017

Accepted 8th May 2017

DOI: $10.1039 / c 7 r a 01785 e$

rsc.li/rsc-advances

\section{Phragmalin-type limonoids from the roots of Trichilia sinensis $\dagger$}

\author{
Shou-Bai Liu, \$ Hui-Qin Chen, Zhi-Kai Guo, Wen-Hua Dong, Jun Wang, Wen-Li Mei* \\ and Hao-Fu Dai $\mathbb{D}$ *
}

Twelve new phragmalin-type limonoids, including trichisintons $A-D(1-4)$, which contain an unusual bicyclo[5.2.1 ${ }^{4,10}$ decane motif in the tetranortriterpenoid core, and trisinenmalins $A-C$ and $E-I$ (5-7 and 10-14), together with the known compounds 15 -acetyltrichagmalin $C$ (8) and trisinenmalin $D(9)$, were isolated from the roots of Trichilia sinensis. Their structures were determined on the basis of the analysis of MS and NMR spectroscopic data, as well as by comparison with the literature. Compounds 5-7 and 10-14 displayed weak inhibitory activity against selected tumor cell lines. Compounds 2-4, 6-9 and 1214 exhibited weak acetylcholinesterase-inhibiting activity in vitro.

\section{Introduction}

Natural products play an important role in the discovery of new drugs, because the great structural diversity of natural products with their various significant biological activities has always been an important source of inspiration for medicinal chemists in their search for new drug leads with pharmacological activities. ${ }^{\mathbf{1 - 4}}$ Limonoids, which are a class of tetranortriterpenoids with a $\beta$-substituted furan ring, are secondary metabolites that are mainly found in the Rutaceae and Meliaceae families ${ }^{5}$ and have attracted continuous attention owing to their diverse structures and various pharmacological activities, including antitumor, antimicrobial, antiprotozoal ${ }^{6,7}$ and neuroprotective effects. $^{8}$

Rearranged limonoids with three uncommon carbon frameworks (mexicanolide-type, phragmalin-type, and trijugintype) have been found in the Trichilia genus, ${ }^{7}$ among which the phragmalin-type and modified phragmalin-type limonoids possess characteristic tricyclo[3.3.1 $\left.1^{2,10} \cdot 1^{1,4}\right]$ decane and bicyclo [5.2.1 $\left.{ }^{4,10}\right]$ decane rings. ${ }^{7}$ Trichilia sinensis Bentv., which is a member of the Trichilia genus (Meliaceae) known to be rich in limonoids, ${ }^{9-15}$ triterpenoids, ${ }^{\mathbf{1 6}, 17}$ diterpenoids ${ }^{\mathbf{1 8 , 1 9}}$ and steroids, ${ }^{\mathbf{2 0 , 2 1}}$ is a shrub that is mainly distributed in China and Vietnam $^{22}$ of which the fruits, leaves and roots have historically been used as folk medicines to treat abdominal pain caused by Ascaris lumbricoides, chronic osteomyelitis, scabies, eczema, ${ }^{23}$ rheumatism and traumatic injury. ${ }^{24}$ A previous investigation of

Laboratory of Biology and Genetic Resources of Tropical Crops, Ministry of Agriculture, Institute of Tropical Bioscience and Biotechnology, Chinese Academy of Tropical Agricultural Sciences, Haikou 571101, P. R. China. E-mail: meiwenli@itbb.org.cn; daihaofu@itbb.org.cn; Fax: +86-898-66961869; Tel: +86-898-66961869

$\dagger$ Electronic supplementary information (ESI) available: 1D and 2D NMR spectra and mass spectra of 1-7 and 9-14. See DOI: 10.1039/c7ra01785e

\$ These authors contributed equally to this work. the chemical constituents of $T$. sinensis revealed a series of mexicanolide-type limonoids,${ }^{25}$ whereas phragmalin-type limonoids have never been reported from this species.

To investigate more structurally interesting and bioactive limonoids, 12 new phragmalin-type limonoids, namely, trichisintons A-D (1-4) and trisinenmalins A-C and E-I (5-7 and 1014), together with the two known analogs 15-acetyltrichagmalin C (8) and trisinenmalin D (9) (Fig. 1), were isolated from the roots of $T$. sinensis. Trichisintons A-D (1-4) possess an unusual bicyclo $\left[5.2 .1^{4,10}\right]$ decane motif in the tetranortriterpenoid core.
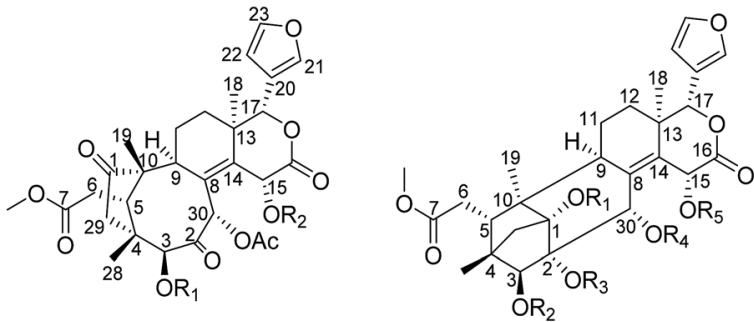

$$
\begin{aligned}
& 1 \mathrm{R}_{1}=\mathrm{R}_{2}=\mathrm{A} 1 \\
& 2 \mathrm{R}_{1}=\mathrm{R}_{2}=\mathrm{A} 2 \\
& 3 \mathrm{R}_{1}=\text { Tig, } \mathrm{R}_{2}=\mathrm{A} 1 \\
& 4 \mathrm{R}_{1}=\text { Tig, } \mathrm{R}_{2}=\mathrm{A} 2
\end{aligned}
$$

$$
\begin{aligned}
& 5 \mathrm{R}_{1}=\mathrm{Ac}, \mathrm{R}_{2}=\text { Tig, } \mathrm{R}_{3}=\mathrm{H}, \mathrm{R}_{4}=\mathrm{Ac}, \mathrm{R}_{5}=\mathrm{A} 1 \\
& 6 \mathrm{R}_{1}=\mathrm{H}, \mathrm{R}_{2}=\mathrm{Tig}, \mathrm{R}_{3}=\mathrm{H}, \mathrm{R}_{4}=\mathrm{H}, \mathrm{R}_{5}=\mathrm{A} 2 \\
& 7 \mathrm{R}_{1}=\mathrm{H}, \mathrm{R}_{2}=\mathrm{Tig}, \mathrm{R}_{3}=\mathrm{H}, \mathrm{R}_{4}=\mathrm{Ac}, \mathrm{R}_{5}=\mathrm{A} 2 \\
& 8 \mathrm{R}_{1}=\mathrm{H}, \mathrm{R}_{2}=\mathrm{Tig}, \mathrm{R}_{3}=\mathrm{H}, \mathrm{R}_{4}=\mathrm{A} 1, \mathrm{R}_{5}=\mathrm{Ac} \\
& 9 \mathrm{R}_{1}=\mathrm{Ac}, \mathrm{R}_{2}=\mathrm{Tig}, \mathrm{R}_{3}=\mathrm{Ac}, \mathrm{R}_{4}=\mathrm{Ac}, \mathrm{R}_{5}=\mathrm{A} 1 \\
& 10 \mathrm{R}_{1}=\mathrm{Ac}, \mathrm{R}_{2}=\mathrm{A} 1, \mathrm{R}_{3}=\mathrm{Ac}, \mathrm{R}_{4}=\mathrm{Ac}, \mathrm{R}_{5}=\mathrm{A} 1 \\
& 11 \mathrm{R}_{1}=\mathrm{H}, \mathrm{R}_{2}=\mathrm{A} 1, \mathrm{R}_{3}=\mathrm{Ac}, \mathrm{R}_{4}=\mathrm{Ac}, \mathrm{R}_{5}=\mathrm{A} 1 \\
& 12 \mathrm{R}_{1}=\mathrm{H}, \mathrm{R}_{2}=\mathrm{A} 2, \mathrm{R}_{3}=\mathrm{H}, \mathrm{R}_{4}=\mathrm{Ac}, \mathrm{R}_{5}=\mathrm{A} 1 \\
& 13 \mathrm{R}_{1}=\mathrm{Ac}, \mathrm{R}_{2}=\mathrm{A} 1, \mathrm{R}_{3}=\mathrm{H}, \mathrm{R}_{4}=\mathrm{Ac}, \mathrm{R}_{5}=\mathrm{A} 1 \\
& 14 \mathrm{R}_{1}=\mathrm{H}, \mathrm{R}_{2}=\mathrm{A} 1, \mathrm{R}_{3}=\mathrm{H}, \mathrm{R}_{4}=\mathrm{Ac}, \mathrm{R}_{5}=\mathrm{A} 1
\end{aligned}
$$
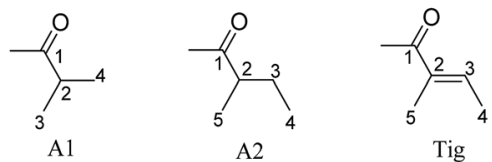

Fig. 1 Structures of compounds 1-14. 
Structurally, the 1,2-dihydroxyphragmalin-type limonoids (6-8, 12, and 14) are the key precursors in the synthesis of the trichiliton-type limonoids (1-4) in a hypothetical biosynthetic pathway. ${ }^{26}$ Here, the isolation process, structural determination, and bioactivity, including cytotoxicity and acetylcholinesterase-inhibiting activity, of these compounds are described.

\section{Results and discussion}

\section{Structural determination of new compounds 1-4, 5-7 and 10- 14}

Trichisinton A (1) was isolated as a white, amorphous powder, and its molecular formula $\mathrm{C}_{37} \mathrm{H}_{46} \mathrm{O}_{13}$, which was established by HREIMS $\left(\mathrm{m} / \mathrm{z}\right.$ 698.2935 $[\mathrm{M}]^{+}$, calcd as 698.2938), requires 15 degrees of unsaturation. The IR absorption at $1750 \mathrm{~cm}^{-1}$ showed the presence of a carbonyl group. The ${ }^{13} \mathrm{C}$ NMR data (Table 2) displayed 37 carbon resonances, which were classified as nine methyl (one $O$-methyl), four methylene, eleven methine (three olefinic and four oxygenated), and 13 quaternary (three olefinic and seven carbonyl) carbons, which was supported by the DEPT and HSQC spectra. A typical $\beta$-substituted furan ring $\left(\delta_{\mathrm{H}} 6.40,7.41\right.$, and $7.43 ; \delta_{\mathrm{C}} 109.8,120.3,142.0$ and 143.5), two keto carbonyls $\left(\delta_{\mathrm{C}} 219.2,199.9\right)$, and five ester carbonyls $\left(\delta_{\mathrm{C}}\right.$ 167.6, 168.7, 173.9, 175.3, and 176.1) were evident from the NMR data (Tables 1 and 2). Furthermore, one acetoxy and two isobutyryloxy groups were inferred according to the ${ }^{1} \mathrm{H}-{ }^{1} \mathrm{H}$ COSY and HMBC correlations (Fig. 2). The above observations accounted for 11 of the 15 degrees of unsaturation and suggested that 1 is a limonoid analogue with four additional rings. The two geminal methylene protons $\left[\delta_{\mathrm{H}} 2.54(\mathrm{~d}, 16.8 \mathrm{~Hz}), 2.38\right.$ $\left.(\mathrm{d}, 16.8 \mathrm{~Hz}) ; \delta_{\mathrm{C}} 44.4\right]$ at C-29 were assigned by the HMBC correlations with the ketone carbonyl C-1 $\left(\delta_{\mathrm{C}} 219.2\right), \mathrm{C}-3\left(\delta_{\mathrm{C}}\right.$ 83.8), C-4 $\left(\delta_{\mathrm{C}} 45.7\right), \mathrm{C}-5\left(\delta_{\mathrm{C}} 40.9\right), \mathrm{C}-10\left(\delta_{\mathrm{C}} 54.1\right)$ and C-28 $\left(\delta_{\mathrm{C}}\right.$ 21.9). The key HMBC correlations from $\mathrm{H}-5\left(\delta_{\mathrm{H}} 3.62\right)$ to $\mathrm{C}-1, \mathrm{C}-3$, C-4, C-6 $\left(\delta_{\mathrm{C}} 33.1\right)$, C-9 and C-10, as well as from the singlet methyl protons at $\delta_{\mathrm{H}} 0.95\left(\mathrm{H}_{3}-19\right)$ to $\mathrm{C}-1, \mathrm{C}-5$ and $\mathrm{C}-10$, suggested that a cyclopentanone ring was constructed by C-1, C-29, C-4, C-5 and C-10, which was characteristic of trichiliton-type limonoids with an unusual bicyclo $\left[5.2 .1^{4,10}\right]$ decane motif in the tetranortriterpenoid core. A comparison of the NMR data revealed great similarity to those of trichiliton A. $^{26}$ Detailed analysis of the $1 \mathrm{D}\left({ }^{1} \mathrm{H} \mathrm{NMR},{ }^{13} \mathrm{C}\right.$ NMR and DEPT $)$ and $2 \mathrm{D}$ NMR data $\left({ }^{1} \mathrm{H}-{ }^{1} \mathrm{H}\right.$ COSY, HSQC and HMBC) indicated that both compounds shared the same skeleton, and the major differences were the substituents at C-3, C-15 and C-30, as well as the carbonyl carbon at C-2 instead of the double bond between $\mathrm{C}-2$ and $\mathrm{C}-3$ in the known compound trichiliton A, which was supported by the downfield chemical shift of C-2 $\left(\delta_{\mathrm{C}} 199.9\right)$ and the HMBC correlations from $\mathrm{H}-3\left(\delta_{\mathrm{H}} 5.33\right)$ and $\mathrm{H}-30\left(\delta_{\mathrm{H}} 5.77\right)$ to $\mathrm{C}-2$. In addition, the two isobutyryloxy groups at C-3 and C-15, respectively, and the acetoxy substituent at C-30 were assigned

Table $1{ }^{1} \mathrm{H}$ NMR $(500 \mathrm{MHz})$ data of compounds $1-4\left(\mathrm{CDCl}_{3}, \delta_{\mathrm{H}}\right.$ in ppm, J in Hz)

\begin{tabular}{|c|c|c|c|c|}
\hline Position & 1 & 2 & 3 & 4 \\
\hline 3 & $5.33 \mathrm{~s}$ & $5.36 \mathrm{~s}$ & $5.00 \mathrm{~s}$ & $5.00 \mathrm{~s}$ \\
\hline 5 & 3.62 br d (12.4) & 3.60 br d (12.0) & 3.70 br d (12.3) & 3.71 br d (12.3) \\
\hline $6 a$ & $2.46 \mathrm{~m}$ & $2.46 \mathrm{dd}(12.3,16.3)$ & $2.52 \mathrm{~m}$ & $2.51 \mathrm{~d}(17.1)$ \\
\hline $6 b$ & $2.37 \mathrm{dd}(16.3,1.8)$ & $2.36 \mathrm{~d}(16.0)$ & $2.39 \mathrm{~m}$ & $2.42 \mathrm{~d}(17.1)$ \\
\hline 9 & $3.02 \mathrm{~d}(3.0)$ & $3.01 \mathrm{br} \mathrm{s}$ & $3.01 \mathrm{~d}(3.2)$ & $3.01 \mathrm{~d}(2.8)$ \\
\hline $11 \alpha$ & $1.65 \mathrm{~m}$ & $1.66 \mathrm{~m}$ & $1.61 \mathrm{~m}$ & $1.63 \mathrm{~m}$ \\
\hline $11 \beta$ & $1.96 \mathrm{~d}(14.8)$ & $1.96 \mathrm{~d}(14.7)$ & $1.94 \mathrm{~d}(14.8)$ & $1.94 \mathrm{~d}(14.8)$ \\
\hline $12 \alpha$ & $1.04 \mathrm{~m}$ & $1.06 \mathrm{~m}$ & $1.05 \mathrm{~m}$ & $1.05 \mathrm{~m}$ \\
\hline $12 \beta$ & 1.23 overlapped & $1.18 \mathrm{~m}$ & 1.20 overlapped & $1.18 \mathrm{~m}$ \\
\hline 15 & $6.64 \mathrm{~d}(0.7)$ & 6.62 br s & $6.41 \mathrm{~s}$ & $6.41 \mathrm{~s}$ \\
\hline 17 & $5.88 \mathrm{~s}$ & $5.90 \mathrm{~s}$ & $5.82 \mathrm{~s}$ & $5.82 \mathrm{~s}$ \\
\hline 18 & $1.23 \mathrm{~s}$ & $1.22 \mathrm{~s}$ & $1.20 \mathrm{~s}$ & $1.20 \mathrm{~s}$ \\
\hline 19 & $0.95 \mathrm{~s}$ & $0.95 \mathrm{~s}$ & $0.95 \mathrm{~s}$ & $0.96 \mathrm{~s}$ \\
\hline 21 & $7.41 \mathrm{~s}$ & $7.43 \mathrm{~s}$ & $7.45 \mathrm{~s}$ & $7.45 \mathrm{~s}$ \\
\hline 22 & $6.40 \mathrm{br} \mathrm{s}$ & $6.41 \mathrm{~s}$ & $6.41 \mathrm{~s}$ & $6.41 \mathrm{~s}$ \\
\hline 23 & $7.43 \mathrm{t}(1.6)$ & $7.43 \mathrm{~s}$ & 7.43 t (1.9) & $7.44 \mathrm{~s}$ \\
\hline 28 & $1.07 \mathrm{~s}$ & $1.09 \mathrm{~s}$ & $1.15 \mathrm{~s}$ & $1.15 \mathrm{~s}$ \\
\hline $29 \alpha$ & $2.38 \mathrm{~d}(16.8)$ & $2.38 \mathrm{~d}(17.3)$ & $2.39 \mathrm{~d}(17.2)$ & $2.39 \mathrm{~d}(17.1)$ \\
\hline $29 \beta$ & $2.54 \mathrm{~d}(16.8)$ & $2.55 \mathrm{~d}(17.3)$ & $2.55 \mathrm{~d}(17.2)$ & $2.56 \mathrm{~d}(17.1)$ \\
\hline 30 & $5.77 \mathrm{~s}$ & $5.79 \mathrm{~s}$ & $5.67 \mathrm{~s}$ & $5.67 \mathrm{~s}$ \\
\hline MeO-7 & $3.71 \mathrm{~s}$ & $3.70 \mathrm{~s}$ & $3.76 \mathrm{~s}$ & $3.76 \mathrm{~s}$ \\
\hline $\mathrm{R}_{1}-2^{\prime}$ & $2.84 \mathrm{~m}$ & $2.67 \mathrm{~m}$ & & \\
\hline $3^{\prime}$ & $1.29 \mathrm{~d}(6.9)$ & $1.81 \mathrm{~m} 1.55 \mathrm{~m}$ & $7.35 \mathrm{dq}(7.0,1.0)$ & $7.35 \mathrm{q}(6.9)$ \\
\hline $4^{\prime}$ & $1.28 \mathrm{~d}(6.9)$ & $0.91 \mathrm{t}(7.5)$ & $1.82 \mathrm{~d}(7.0)$ & $1.82 \mathrm{~d}(6.9)$ \\
\hline $5^{\prime}$ & & $1.28 \mathrm{~d}(6.8)$ & $1.98 \mathrm{~s}$ & $1.99 \mathrm{~s}$ \\
\hline $\mathrm{R}_{2}-2^{\prime \prime}$ & $2.47 \mathrm{~m}$ & $2.28 \mathrm{~m}$ & $2.42 \mathrm{~m}$ & $2.24 \mathrm{~m}$ \\
\hline $3^{\prime \prime}$ & $1.17 \mathrm{~d}(7.0)$ & $1.81 \mathrm{~m} 1.55 \mathrm{~m}$ & $1.14 \mathrm{~d}(7.0)$ & $1.76 \mathrm{~m} 1.49 \mathrm{~m}$ \\
\hline $4^{\prime \prime}$ & $1.23 \mathrm{~d}(7.0)$ & 0.97 t (7.5) & $1.18 \mathrm{~d}(7.0)$ & $0.93 \mathrm{t}(7.4)$ \\
\hline $5^{\prime \prime}$ & & $1.14 \mathrm{~d}(6.9)$ & & $1.11 \mathrm{~d}(6.9)$ \\
\hline OAc-30 & $2.11 \mathrm{~s}$ & $2.11 \mathrm{~s}$ & $2.09 \mathrm{~s}$ & $2.09 \mathrm{~s}$ \\
\hline
\end{tabular}


Table $2{ }^{13} \mathrm{C}$ NMR $(125 \mathrm{MHz})$ data of compounds $1-4\left(\mathrm{CDCl}_{3}, \delta_{\mathrm{C}}\right.$ in ppm)

\begin{tabular}{|c|c|c|c|c|}
\hline Position & 1 & 2 & 3 & 4 \\
\hline 1 & 219.2 & 219.2 & 219.2 & 219.2 \\
\hline 2 & 199.9 & 200.0 & 200.6 & 200.5 \\
\hline 3 & 83.8 & 83.8 & 84.8 & 84.8 \\
\hline 4 & 45.7 & 45.6 & 45.0 & 45.0 \\
\hline 5 & 40.9 & 41.0 & 41.1 & 41.1 \\
\hline 6 & 33.1 & 33.2 & 33.3 & 33.4 \\
\hline 7 & 173.9 & 173.8 & 174.2 & 174.1 \\
\hline 8 & 134.5 & 134.4 & 134.3 & 134.4 \\
\hline 9 & 39.2 & 39.3 & 39.3 & 39.3 \\
\hline 10 & 54.1 & 54.1 & 54.2 & 54.2 \\
\hline 11 & 21.4 & 21.4 & 21.4 & 21.4 \\
\hline 12 & 28.5 & 28.5 & 28.5 & 28.6 \\
\hline 13 & 40.4 & 40.5 & 40.4 & 40.4 \\
\hline 14 & 141.6 & 141.8 & 141.8 & 141.9 \\
\hline 15 & 64.5 & 64.4 & 64.1 & 64.0 \\
\hline 16 & 167.6 & 167.6 & 167.6 & 167.6 \\
\hline 17 & 79.8 & 79.8 & 79.6 & 79.7 \\
\hline 18 & 17.9 & 17.4 & 17.3 & 17.4 \\
\hline 19 & 23.9 & 24.0 & 24.0 & 24.0 \\
\hline 20 & 120.3 & 120.4 & 120.5 & 120.5 \\
\hline 21 & 142.0 & 142.0 & 142.0 & 142.0 \\
\hline 22 & 109.8 & 109.8 & 109.9 & 109.9 \\
\hline 23 & 143.5 & 143.4 & 143.5 & 143.5 \\
\hline 28 & 21.9 & 22.0 & 21.9 & 22.0 \\
\hline 29 & 44.4 & 44.4 & 44.0 & 44.0 \\
\hline 30 & 74.7 & 74.8 & 74.5 & 74.6 \\
\hline MeO-7 & 52.5 & 52.5 & 52.5 & 52.6 \\
\hline $\mathrm{R}_{1}-1^{\prime}$ & 176.1 & 175.5 & 166.7 & 166.8 \\
\hline $2^{\prime}$ & 34.0 & 41.0 & 129.4 & 129.4 \\
\hline $3^{\prime}$ & 20.7 & 26.9 & 140.1 & 140.1 \\
\hline $4^{\prime}$ & 18.6 & 11.4 & 14.7 & 14.7 \\
\hline $5^{\prime}$ & & 15.4 & 12.5 & 12.5 \\
\hline $\mathrm{R}_{2}-1^{\prime \prime}$ & 175.3 & 174.7 & 174.5 & 174.1 \\
\hline $2^{\prime \prime}$ & 34.5 & 40.3 & 33.8 & 40.3 \\
\hline $3^{\prime \prime}$ & 17.3 & 26.6 & 19.1 & 26.5 \\
\hline $4^{\prime \prime}$ & 19.2 & 11.3 & 17.3 & 11.4 \\
\hline $5^{\prime \prime}$ & & 14.8 & & 14.9 \\
\hline \multirow[t]{2}{*}{ OAc-30 } & 168.7 & 168.7 & 168.3 & 168.3 \\
\hline & 19.9 & 20.7 & 20.7 & 20.7 \\
\hline
\end{tabular}

by the relevant HMBC correlations, as shown in Fig. 2. Thus, the planar structure of 1 was established, as shown in Fig. 1.

The relative configuration of 1 (ESI Fig. S92 $\dagger$ ) was determined by the ROESY spectrum. The ROESY correlations of $\mathrm{H}-5$ / $\mathrm{H}-17, \mathrm{H}-5 / \mathrm{H}_{3}-28, \mathrm{H}-5 / \mathrm{H}-30, \mathrm{H}-30 / \mathrm{H}-15, \mathrm{H}-5 / \mathrm{H}-15, \mathrm{H}-15 / \mathrm{H}-2^{\prime}$, and $\mathrm{H}-11 \beta / \mathrm{H}-19$ indicated that these protons and the isobutyryl group at $\mathrm{C}-3$ were all $\beta$-oriented, whereas the ROESY correlations of $\mathrm{H}-22 / \mathrm{H}_{3}-18, \mathrm{H}_{3}-18 / \mathrm{H}-11 \alpha, \mathrm{H}-9 / \mathrm{H}-29 \alpha$, and $\mathrm{H}-29 \alpha / \mathrm{H}-3$ revealed the $\alpha$-orientation of the corresponding protons. Therefore, the structure of compound 1 was finally established.

Trichisinton B (2) was assigned a molecular formula of $\mathrm{C}_{39} \mathrm{H}_{50} \mathrm{O}_{13}$, as established on the basis of the prominent HRESIMS ion peak at $m / z 749.3158\left([\mathrm{M}+\mathrm{Na}]^{+}\right.$, calcd for $\mathrm{C}_{39} \mathrm{H}_{50} \mathrm{O}_{13} \mathrm{Na}$ 749.3149). The NMR spectroscopic data indicated that 2 had a similar skeleton to that of $\mathbf{1}$, except for the different substitution patterns at C-3 and C-15. Instead of isobutyryloxy groups, compound 2 possessed two 2-methylbutanoate groups at C-3 $\left(\delta_{\mathrm{C}}\right.$ 83.8) and C-15 ( $\left.\delta_{\mathrm{C}} 64.4\right)$, respectively, on the basis of the corresponding ${ }^{1} \mathrm{H}-{ }^{1} \mathrm{H}$ COSY correlations of $\mathrm{H}-2^{\prime}\left(\mathrm{H}-2^{\prime \prime}\right) / \mathrm{H}-3^{\prime}(\mathrm{H}-$ $\left.3^{\prime \prime}\right), \mathrm{H}-3^{\prime}\left(\mathrm{H}-3^{\prime \prime}\right) / \mathrm{H}-4^{\prime}\left(\mathrm{H}-4^{\prime \prime}\right)$ and $\mathrm{H}-2^{\prime}\left(\mathrm{H}-2^{\prime \prime}\right) / \mathrm{H}-5^{\prime}\left(\mathrm{H}-5^{\prime \prime}\right)$, as well as the HMBC correlations from $\mathrm{H}-2^{\prime}\left(\delta_{\mathrm{H}} 2.67 ; \mathrm{H}-2^{\prime \prime}, \delta_{\mathrm{H}} 2.28\right)$ to $\mathrm{C}-1^{\prime}$ $\left(\delta_{\mathrm{C}} 175.5 ; \mathrm{C}-1^{\prime \prime}, \delta_{\mathrm{C}} 174.7\right)$. The attachment of these two moieties to $\mathrm{C}-3$ and $\mathrm{C}-15$ was deduced from the HMBC correlations from $\mathrm{H}-3\left(\delta_{\mathrm{H}} 5.36\right)$ to $\mathrm{C}-1^{\prime}\left(\delta_{\mathrm{C}} 175.5\right)$ and from $\mathrm{H}-15\left(\delta_{\mathrm{H}} 6.62\right)$ to $\mathrm{C}-1^{\prime \prime}$ $\left(\delta_{\mathrm{C}} 174.7\right)$, respectively (Fig. 2$)$. The relative configuration was found to be the same as that of $\mathbf{1}$ by an ROESY experiment (ESI Fig. S92†).

Trichisinton $\mathrm{C}$ (3), which was a white, amorphous powder, had a molecular formula of $\mathrm{C}_{38} \mathrm{H}_{46} \mathrm{O}_{13}$ on the basis of its prominent HRESIMS ion peak at $m / z 749.2578\left([\mathrm{M}+\mathrm{K}]^{+}\right.$, $\mathrm{C}_{38} \mathrm{H}_{46} \mathrm{O}_{13} \mathrm{~K}$ calcd as 749.2570). A comparison between the NMR data (Tables 1 and 2) of $\mathbf{1}$ and $\mathbf{3}$ showed that the tiglyloxy group at $\mathrm{C}-3$ in $\mathbf{3}$ was not present in $\mathbf{1}$, which was confirmed by the HMBC correlations from $\mathrm{H}-5^{\prime}\left(\delta_{\mathrm{H}} 1.98\right)$ to $\mathrm{C}-1^{\prime}\left(\delta_{\mathrm{C}} 166.7\right), \mathrm{C}-2^{\prime}\left(\delta_{\mathrm{C}}\right.$ 129.4) and $\mathrm{C}-3^{\prime}\left(\delta_{\mathrm{C}} 140.1\right)$, and from $\mathrm{H}-4^{\prime}\left(\delta_{\mathrm{H}} 1.82\right)$ to $\mathrm{C}-3^{\prime}$. The attachment of this moiety to $\mathrm{C}-3$ was determined by the crosspeak of $\mathrm{H}-3\left(\delta_{\mathrm{H}} 5.00\right) / \mathrm{C}-1^{\prime}$ in the HMBC spectrum. Similarly, instead of a 2-methylbutanoate group, an isobutyryloxy moiety was found to be connected to C-15 as a result of the HMBC correlations from $\mathrm{H}-2^{\prime \prime}\left(\delta_{\mathrm{H}} 2.42\right)$ to $\mathrm{C}-1^{\prime \prime}\left(\delta_{\mathrm{C}}\right.$ 174.7) (Fig. 2). Therefore, the structure of trichisinton $\mathrm{C}(3)$ was determined, as shown in Fig. 1.

Trichisinton D (4), which was a white, amorphous powder, displayed a peak for $[\mathrm{M}+\mathrm{K}]^{+}$at $m / z 763.2726$ (calcd for $\mathrm{C}_{39} \mathrm{H}_{48} \mathrm{O}_{13} \mathrm{~K}$ 763.2726) in the HRESIMS spectrum, which was 14 mass units greater than that of 3 . Detailed analysis of the ${ }^{1} \mathrm{H}$ and ${ }^{13} \mathrm{C}$ NMR data of 4 revealed a structure that was closely related to that of 3 , and the major difference was the replacement of the isobutyryloxy group at C-15 by a 2-methylbutanoate group in 4. The 2-methylbutanoate group was confirmed by the ${ }^{1} \mathrm{H}-{ }^{1} \mathrm{H}$ COSY correlations of $\mathrm{H}-2^{\prime \prime} / \mathrm{H}-3^{\prime \prime}, \mathrm{H}-3^{\prime \prime} / \mathrm{H}-4^{\prime \prime}$ and $\mathrm{H}-2^{\prime \prime} / \mathrm{H}-$ $5^{\prime \prime}$, as well as the HMBC correlations from $\mathrm{H}-2^{\prime \prime}\left(\delta_{\mathrm{H}} 2.24\right)$ to $\mathrm{C}-1^{\prime \prime}$ $\left(\delta_{\mathrm{C}} 174.1\right)$. The connection with $\mathrm{C}-15$ was confirmed as a result of the HMBC correlations from $\mathrm{H}-15\left(\delta_{\mathrm{H}} 6.41\right)$ to $\mathrm{C}-13\left(\delta_{\mathrm{C}} 40.4\right)$, $\mathrm{C}-14\left(\delta_{\mathrm{C}}\right.$ 141.9), C-16 ( $\delta_{\mathrm{C}}$ 167.6) and C-1" $\left(\delta_{\mathrm{C}}\right.$ 174.1) (Fig. 2). Therefore, the structure of 4 was established, as shown in Fig. 1, with the same relative configuration as that of $\mathbf{1}$ according to the ROESY spectrum.

Trisinenmalin A (5) was isolated as a white, amorphous powder, and its molecular formula of $\mathrm{C}_{40} \mathrm{H}_{50} \mathrm{O}_{14}$, which was established by the HRESIMS spectrum $\left(\mathrm{m} / z\right.$ 777.3099 $[\mathrm{M}+\mathrm{Na}]^{+}$, calcd as 777.3098), requires 16 degrees of unsaturation. Its IR absorption bands showed the presence of hydroxy $\left(3444 \mathrm{~cm}^{-1}\right)$ and carbonyl groups $\left(1729 \mathrm{~cm}^{-1}\right)$. The ${ }^{13} \mathrm{C}$ NMR and DEPT spectroscopic data of 5 displayed 40 carbon signals, which was in agreement with the molecular formula, including ten methyl (one methoxy group), four methylene, eleven methine (four oxygenated and four olefinic), and fifteen quaternary carbons (six carbonyl and four olefinic). Furthermore, one tiglyloxy, one isobutyryloxy, and two acetoxy groups were inferred according to the HMBC correlations and ${ }^{1} \mathrm{H}-{ }^{1} \mathrm{H}$ COSY correlations (Fig. 2). In addition, the typical $\beta$-furan moiety $\left(\delta_{\mathrm{H}} 6.46,7.39\right.$ and $7.57 ; \delta_{\mathrm{C}}$ $110.0,120.6,142.1$ and 143.1) was deduced. The above fragments, together with the remaining 23 carbons, revealed that 5 was a limonoid with six rings, which was consistent with the 

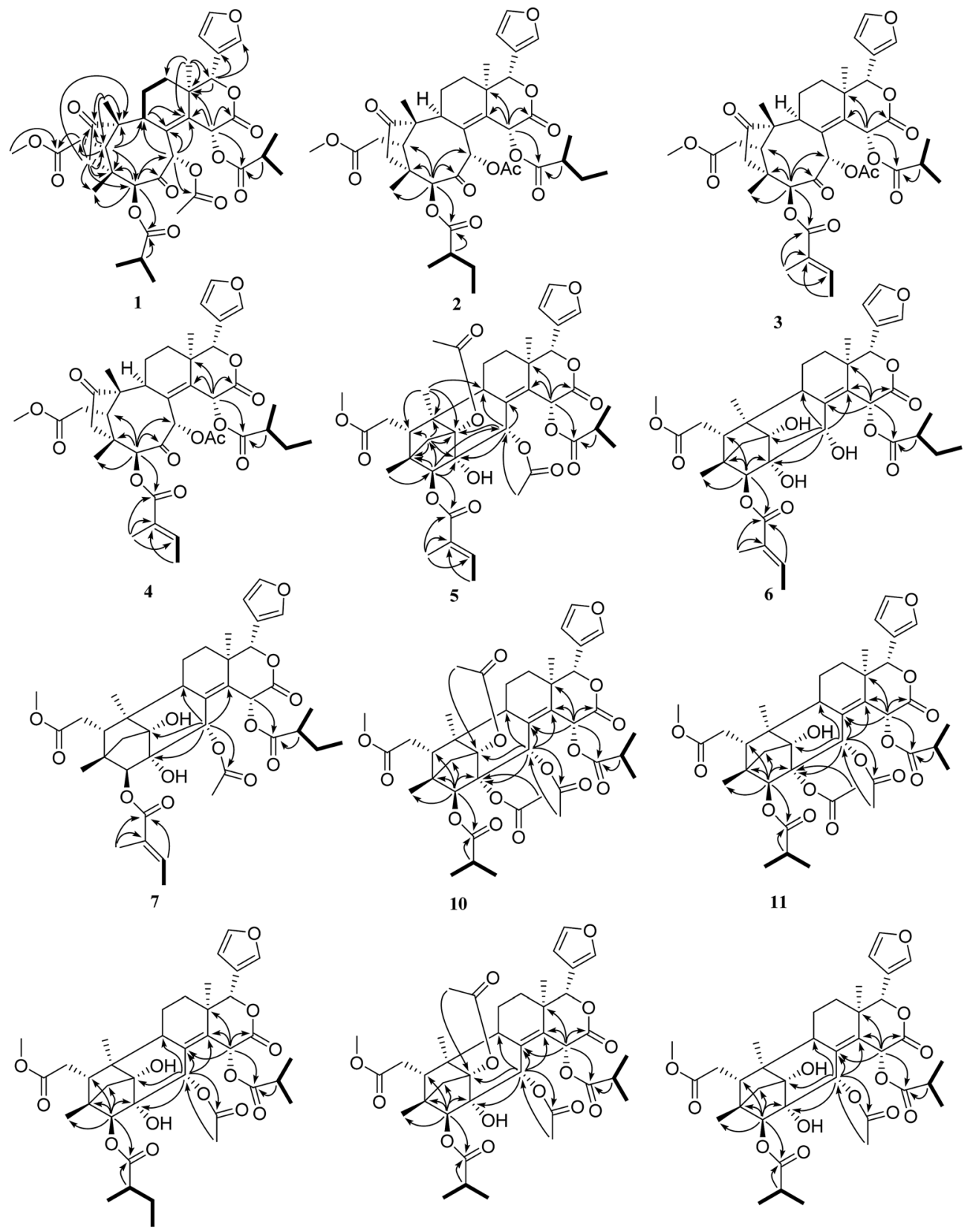

11

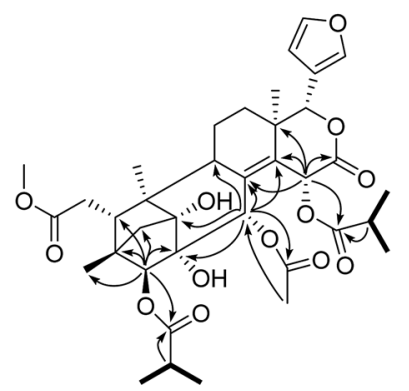

12

13

14

Fig. 2 Key ${ }^{1} \mathrm{H}-{ }^{1} \mathrm{H} \operatorname{COSY}(-)$ and $\mathrm{HMBC}(\mathrm{H} \rightarrow \mathrm{C})$ correlations of 1-7 and 10-14.

degree of unsaturation. In the $\mathrm{HMBC}$ spectrum, the key correlations from $\mathrm{H}-30\left(\delta_{\mathrm{H}} 5.39\right)$ to $\mathrm{C}-1\left(\delta_{\mathrm{C}} 89.1\right), \mathrm{C}-8\left(\delta_{\mathrm{C}} 134.2\right)$ and $\mathrm{C}-$ $9\left(\delta_{\mathrm{C}} 36.4\right)$, from H-3 $\left(\delta_{\mathrm{H}} 4.70\right)$ to C-2 $\left(\delta_{\mathrm{C}} 77.8\right), \mathrm{C}-5\left(\delta_{\mathrm{C}} 36.1\right)$ and $\mathrm{C}-29\left(\delta_{\mathrm{C}} 38.4\right)$, and from $\mathrm{H}-29\left(\delta_{\mathrm{H}} 2.40,2.51\right)$ to $\mathrm{C}-1, \mathrm{C}-2, \mathrm{C}-4\left(\delta_{\mathrm{C}}\right.$ $44.3), \mathrm{C}-5$ and $\mathrm{C}-10\left(\delta_{\mathrm{C}} 49.4\right)$, as well as from $\mathrm{H}-19\left(\delta_{\mathrm{H}} 1.06\right)$ to $\mathrm{C}-$ $1, \mathrm{C}-5, \mathrm{C}-9$ and $\mathrm{C}-10$, confirmed the presence of a tricyclo $\left[3.3 .1^{2,10} \cdot 1^{1,4}\right.$ ]decane moiety, which was characteristic of phragmalin-type limonoids. ${ }^{27}$ By comparison of the ${ }^{1} \mathrm{H}$ and ${ }^{13} \mathrm{C}$ NMR data of 5 with those of 1,30-diacetyltrichagmalin $\mathrm{F}^{\mathbf{1 1}}$ it was found that both compounds shared the same skeleton, which was further confirmed by detailed analysis of the 2D NMR data $\left({ }^{1} \mathrm{H}-{ }^{1} \mathrm{H}\right.$ COSY, HSQC and HMBC). The major difference between
5 and the known compound 1,30-diacetyltrichagmalin $\mathrm{F}$ was the replacement of the hydroxyisobutyryl group at C-15 by an isobutyryloxy group in $\mathbf{5}$, which was supported by the HMBC correlations (Fig. 2) from $\mathrm{H}-15\left(\delta_{\mathrm{H}} 6.19\right)$ to $\mathrm{C}-1^{\prime \prime}\left(\delta_{\mathrm{C}} 174.9\right), \mathrm{C}-16$ $\left(\delta_{\mathrm{C}} 167.8\right), \mathrm{C}-14\left(\delta_{\mathrm{C}} 136.4\right)$ and $\mathrm{C}-13\left(\delta_{\mathrm{C}} 39.0\right)$. Therefore, the planar structure of compound 5 was established.

The relative configuration of $\mathbf{5}$ was deduced by analysis of its ROESY spectrum. As shown in ESI Fig. S92, $\dagger$ the observed ROESY correlations of $\mathrm{H}_{3}-28 / \mathrm{H}-5, \mathrm{H}-5 / \mathrm{H}-17, \mathrm{H}-17 / \mathrm{H}-15, \mathrm{H}-17 / \mathrm{H}-$ $3^{\prime}$, and $\mathrm{H}-15 / \mathrm{H}-30$ indicated that these protons and the tiglyl group at $\mathrm{C}-3$ were all $\beta$-oriented, whereas the correlations of $\mathrm{H}$ $22 / \mathrm{H}_{3}-18, \quad \mathrm{H}_{3}-18 / \mathrm{H}-11 \alpha$, and $\mathrm{H}-9 / \mathrm{H}_{3}-19$ revealed the $\alpha$ - 
orientation of the corresponding protons. Therefore, the structure of compound $\mathbf{5}$ was finally established, as shown in Fig. 1.

Trisinenmalin B (6) was isolated as a white, amorphous powder. Its molecular formula of $\mathrm{C}_{37} \mathrm{H}_{48} \mathrm{O}_{12}$ was established by HRESIMS $\left(\mathrm{m} / \mathrm{z}\right.$ 707.3038, calcd for $[\mathrm{M}+\mathrm{Na}]^{+}$707.3038). The NMR data of 6 were similar to those of trichagmalin $F,{ }^{11}$ except for the presence of a 2-methylbutanoate group in 6 instead of the hydroxyisobutyryl group in trichagmalin $\mathrm{F}$. The 2-methylbutanoate group was confirmed by the ${ }^{1} \mathrm{H}-{ }^{1} \mathrm{H}$ COSY correlations of $\mathrm{H}-2^{\prime \prime} / \mathrm{H}-3^{\prime \prime}, \mathrm{H}-3^{\prime \prime} / \mathrm{H}-4^{\prime \prime}$ and $\mathrm{H}-2^{\prime \prime} / \mathrm{H}-5^{\prime \prime}$, as well as the HMBC cross-peak of $\mathrm{H}-2^{\prime \prime}\left(\delta_{\mathrm{H}} 2.44\right) / \mathrm{C}-1^{\prime \prime}\left(\delta_{\mathrm{C}} 175.3\right)$. The connection with C-15 was confirmed by the HMBC cross-peaks from $\mathrm{H}-15\left(\delta_{\mathrm{H}}\right.$ 6.18) to $\mathrm{C}-8\left(\delta_{\mathrm{C}} 138.3\right), \mathrm{C}-13\left(\delta_{\mathrm{C}} 38.6\right), \mathrm{C}-14\left(\delta_{\mathrm{C}} 135.4\right), \mathrm{C}-16\left(\delta_{\mathrm{C}}\right.$ 167.6) and $\mathrm{C}-1^{\prime \prime}\left(\delta_{\mathrm{C}} 175.3\right)$.

The relative configuration of 6 was assigned by an ROESY experiment (ESI Fig. S92 $\dagger$ ) and was found to be the same as that of 5. Therefore, the structure of 6 was confirmed, as shown in Fig. 1.

Trisinenmalin C (7), which was obtained as a white, amorphous powder, displayed a molecular formula of $\mathrm{C}_{39} \mathrm{H}_{50} \mathrm{O}_{13}$, as determined by the prominent HRESIMS ion peak at $\mathrm{m} / \mathrm{z}$ $765.2888\left([\mathrm{M}+\mathrm{K}]^{+}\right.$, calcd as 765.2883), which was 42 mass units more than that of 6. MS and NMR (Tables 3 and 4) analysis indicated that 7 was an acetylated derivative of 6 . On the basis of the coherent HMBC correlation from $\mathrm{H}-30\left(\delta_{\mathrm{H}} 5.42\right)$ to the carbon resonance at $\delta_{\mathrm{C}} 171.1$, the acetoxy group was determined to be located at C-30. Thus, 7 was demonstrated to be the 30acetyl derivative of $\mathbf{6}$, and its relative configuration was found to be the same as that of $\mathbf{6}$ by an ROESY experiment. Therefore, the structure of 7 was established, as shown in Fig. 1.

Trisinenmalin E (10) was obtained as a white, amorphous powder with a molecular formula of $\mathrm{C}_{41} \mathrm{H}_{52} \mathrm{O}_{15}$ (prominent HRESIMS ion peak at $m / z$ 807.3208 $[\mathrm{M}+\mathrm{Na}]^{+}$, calcd as 807.3204). The ${ }^{1} \mathrm{H}$ and ${ }^{13} \mathrm{C}$ NMR data of 10 indicated that its structure was closely related to that of trisinenmalin D (9), and the only difference lay in the presence of an isobutyryloxy group in 10 instead of the tiglyloxy moiety in 9, which was confirmed by the ${ }^{1} \mathrm{H}-{ }^{1} \mathrm{H}$ COSY correlations of $\mathrm{H}-2^{\prime} / \mathrm{H}-3^{\prime}$ and $\mathrm{H}-2^{\prime} / \mathrm{H}-4^{\prime}$ and the HMBC correlation from $\mathrm{H}-2^{\prime}\left(\delta_{\mathrm{H}} 2.62\right)$ to $\mathrm{C}-1^{\prime}\left(\delta_{\mathrm{C}} 176.3\right)$. The attachment of the isobutyryloxy group to $\mathrm{C}-3$ was deduced from the HMBC correlation from $\mathrm{H}-3\left(\delta_{\mathrm{H}} 5.31\right)$ to the carbon resonance at $\delta_{\mathrm{C}}$ 176.3. Accordingly, the structure of trisinenmalin $\mathrm{E}$ (10) was established, as shown in Fig. 1, and the relative configuration was found to be the same as that of $\mathbf{9}$ according to the respective ROESY correlations.

Trisinenmalin $\mathrm{F}$ (11), which was a white amorphous powder, had the molecular formula of $\mathrm{C}_{39} \mathrm{H}_{50} \mathrm{O}_{14}$, as determined by the prominent HRESIMS ion peak at $m / z 765.3109\left([\mathrm{M}+\mathrm{Na}]^{+}\right.$, calcd as 765.3098). Analysis of the MS and NMR data of $\mathbf{1 1}$ indicated

Table $3{ }^{1} \mathrm{H}$ NMR $(500 \mathrm{MHz})$ data of compounds 5-7 and 9-14 $\left(\mathrm{CDCl}_{3}, \delta_{\mathrm{H}}\right.$ in ppm, $\mathrm{J}$ in $\left.\mathrm{Hz}\right)$

\begin{tabular}{|c|c|c|c|c|c|c|c|c|c|}
\hline Position & 5 & 6 & 7 & 9 & 10 & 11 & 12 & 13 & 14 \\
\hline 3 & $4.70 \mathrm{~s}$ & $4.72 \mathrm{~s}$ & $4.71 \mathrm{~s}$ & $5.42 \mathrm{~s}$ & $5.31 \mathrm{~s}$ & $5.31 \mathrm{~s}$ & $5.07 \mathrm{~s}$ & $5.04 \mathrm{~s}$ & $5.02 \mathrm{~s}$ \\
\hline 5 & $2.81 \mathrm{t}(7.0)$ & $2.85 \mathrm{t}(7.0)$ & $2.86 \mathrm{~m}$ & $2.82 \mathrm{~m}$ & $2.69 \mathrm{~m}$ & $2.75 \mathrm{~m}$ & $2.70 \mathrm{~m}$ & $2.67 \mathrm{t}(7.2)$ & $2.73 \mathrm{~m}$ \\
\hline 6 & $2.31 \mathrm{~m}$ & $2.31 \mathrm{~d}(7.2)$ & $2.32 \mathrm{~m}$ & $2.29 \mathrm{~d}(7.3)$ & $2.27 \mathrm{~m}$ & $2.28 \mathrm{~m}$ & $2.26 \mathrm{~m}$ & $2.27 \mathrm{~d}(7.3)$ & $2.28 \mathrm{~m}$ \\
\hline 9 & $2.70 \mathrm{~d}(7.0)$ & $2.61 \mathrm{~d}(6.8)$ & $2.70 \mathrm{~d}(6.8)$ & $2.82 \mathrm{~m}$ & $2.80 \mathrm{~d}(7.4)$ & $2.72 \mathrm{~m}$ & $2.70 \mathrm{~m}$ & $2.71 \mathrm{~d}(6.7)$ & $2.70 \mathrm{~m}$ \\
\hline $11 \alpha$ & $1.70 \mathrm{~m}$ & $1.70 \mathrm{~m}$ & $1.72 \mathrm{~m}$ & $1.77 \mathrm{~m}$ & $1.76 \mathrm{~m}$ & $1.88 \mathrm{~m}$ & $1.73 \mathrm{~m}$ & $1.74 \mathrm{~m}$ & $1.73 \mathrm{~m}$ \\
\hline $11 \beta$ & $1.85 \mathrm{~m}$ & $1.85 \mathrm{~m}$ & $1.88 \mathrm{~m}$ & $1.85 \mathrm{~m}$ & $1.76 \mathrm{~m}$ & $1.88 \mathrm{~m}$ & $1.90 \mathrm{~m}$ & $1.86 \mathrm{~m}$ & $1.89 \mathrm{~m}$ \\
\hline $12 \alpha$ & $1.03 \mathrm{~m}$ & $1.51 \mathrm{~m}$ & $1.04 \mathrm{dt}(13.6,3.0)$ & $1.08 \mathrm{~m}$ & $1.17 \mathrm{~m}$ & $1.08 \mathrm{~m}$ & $1.06 \mathrm{dt}(13.6,3.2)$ & $1.08 \mathrm{~m}$ & $1.07 \mathrm{~d}(13.3)$ \\
\hline $12 \beta$ & $1.38 \mathrm{~m}$ & $1.78 \mathrm{~m}$ & $1.39 \mathrm{~m}$ & $1.45 \mathrm{dt}(13.9,2.2)$ & $1.47 \mathrm{~m}$ & $1.48 \mathrm{~m}$ & $1.46 \mathrm{~m}$ & $1.42 \mathrm{~m}$ & $1.43 \mathrm{t}(13.3)$ \\
\hline 15 & $6.19 \mathrm{~d}(2.0)$ & $6.18 \mathrm{~s}$ & $6.19 \mathrm{~d}(1.8)$ & $6.62 \mathrm{~d}(2.0)$ & $6.73 \mathrm{~d}(2.1)$ & $6.72 \mathrm{~s}$ & $6.56 \mathrm{~d}(2.0)$ & $6.58 \mathrm{~d}(2.0)$ & $6.55 \mathrm{~s}$ \\
\hline 17 & $5.31 \mathrm{~s}$ & $5.27 \mathrm{~s}$ & $5.32 \mathrm{~s}$ & $5.44 \mathrm{~s}$ & $5.48 \mathrm{~s}$ & $5.48 \mathrm{~s}$ & $5.47 \mathrm{~s}$ & $5.48 \mathrm{~s}$ & $5.48 \mathrm{~s}$ \\
\hline 18 & $1.11 \mathrm{~s}$ & $1.13 \mathrm{~s}$ & $1.12 \mathrm{~s}$ & $1.14 \mathrm{~s}$ & $1.17 \mathrm{~s}$ & $1.16 \mathrm{~s}$ & $1.17 \mathrm{~s}$ & $1.16 \mathrm{~s}$ & $1.16 \mathrm{~s}$ \\
\hline 19 & $1.06 \mathrm{~s}$ & $1.11 \mathrm{~s}$ & $1.13 \mathrm{~s}$ & $1.08 \mathrm{~s}$ & $1.07 \mathrm{~s}$ & $1.14 \mathrm{~s}$ & $1.13 \mathrm{~s}$ & $1.06 \mathrm{~s}$ & $1.12 \mathrm{~s}$ \\
\hline 21 & $7.57 \mathrm{~s}$ & $7.57 \mathrm{~s}$ & $7.58 \mathrm{~s}$ & $7.57 \mathrm{~s}$ & $7.57 \mathrm{~s}$ & $7.58 \mathrm{~s}$ & $7.61 \mathrm{~s}$ & $7.56 \mathrm{~s}$ & $7.57 \mathrm{~s}$ \\
\hline 22 & $6.46 \mathrm{~d}(1.6)$ & $6.46 \mathrm{~s}$ & $6.46 \mathrm{~d}(1.0)$ & 6.47 br s & $6.48 \mathrm{~d}(1.7)$ & $6.48 \mathrm{~s}$ & $6.50 \mathrm{~d}(1.6)$ & $6.46 \mathrm{~d}(1.1)$ & $6.47 \mathrm{~s}$ \\
\hline 23 & $7.39 \mathrm{t}(1.6)$ & $7.40 \mathrm{~s}$ & $7.40 \mathrm{t}(1.6)$ & 7.40 br s & $7.40 \mathrm{t}(1.7)$ & $7.39 \mathrm{~s}$ & $7.40 \mathrm{t}(1.6)$ & $7.40 \mathrm{t}(1.6)$ & $7.40 \mathrm{~s}$ \\
\hline 28 & $0.85 \mathrm{~s}$ & $0.84 \mathrm{~s}$ & $0.82 \mathrm{~s}$ & $0.81 \mathrm{~s}$ & $0.81 \mathrm{~s}$ & $0.77 \mathrm{~s}$ & $0.79 \mathrm{~s}$ & $0.81 \mathrm{~s}$ & $0.77 \mathrm{~s}$ \\
\hline $29 a$ & $2.40 \mathrm{~m}$ & $1.61 \mathrm{~d}(10.4)$ & $1.56 \mathrm{~m}$ & $2.39 \mathrm{~d}(12.0)$ & $2.37 \mathrm{~d}(11.7)$ & $1.49 \mathrm{~m}$ & $1.60 \mathrm{~d}(10.6)$ & $2.35 \mathrm{~m}$ & $1.58 \mathrm{~d}(10.9)$ \\
\hline $29 b$ & $2.51 \mathrm{~d}(11.3)$ & $1.86 \mathrm{~d}(10.4)$ & $1.83 \mathrm{~m}$ & $2.47 \mathrm{~m}$ & $2.46 \mathrm{~d}(11.7)$ & $1.49 \mathrm{~m}$ & $1.81 \mathrm{~d}(10.6)$ & $2.48 \mathrm{~m}$ & $1.81 \mathrm{~d}(10.9)$ \\
\hline 30 & $5.39 \mathrm{~s}$ & $4.13 \mathrm{~s}$ & $5.42 \mathrm{~s}$ & $6.13 \mathrm{~s}$ & $6.14 \mathrm{~s}$ & $6.21 \mathrm{~s}$ & $5.51 \mathrm{~s}$ & $5.50 \mathrm{~s}$ & $5.49 \mathrm{~s}$ \\
\hline MeO-7 & $3.71 \mathrm{~s}$ & $3.71 \mathrm{~s}$ & $3.72 \mathrm{~s}$ & $3.68 \mathrm{~s}$ & $3.66 \mathrm{~s}$ & $3.65 \mathrm{~s}$ & $3.66 \mathrm{~s}$ & $3.66 \mathrm{~s}$ & $3.66 \mathrm{~s}$ \\
\hline $\mathrm{R}_{2}-2^{\prime}$ & & & & & $2.62 \mathrm{~m}$ & $2.60 \mathrm{~m}$ & $2.37 \mathrm{~m}$ & $2.57 \mathrm{~m}$ & $2.57 \mathrm{~m}$ \\
\hline $3^{\prime}$ & $7.10 \mathrm{dq}(7.0,1.2)$ & $7.07 \mathrm{dq}(6.9,0.9)$ & $7.11 \mathrm{dq}(7.0,1.1)$ & $6.58 \mathrm{q}(6.8)$ & $1.23 \mathrm{~d}(6.9)$ & $1.31 \mathrm{~d}(6.8)$ & $1.76 \mathrm{~m}, 1.46 \mathrm{~m}$ & $1.22 \mathrm{~d}(7.0)$ & $1.26 \mathrm{~d}(6.8)$ \\
\hline $4^{\prime}$ & $1.74 \mathrm{~d}(7.0)$ & $1.74 \mathrm{~d}(6.9)$ & $1.75 \mathrm{~d}(7.0)$ & $1.69 \mathrm{~d}(6.8)$ & $1.31 \mathrm{~d}(6.9)$ & $1.22 \mathrm{~d}(6.8)$ & 0.86 t $(7.5)$ & $1.22 \mathrm{~d}(7.0)$ & $1.26 \mathrm{~d}(6.8)$ \\
\hline $5^{\prime}$ & $1.99 \mathrm{~s}$ & $1.92 \mathrm{~s}$ & $1.99 \mathrm{~s}$ & $2.02 \mathrm{~s}$ & & & $1.27 \mathrm{~d}(7.3)$ & & \\
\hline $\mathrm{R}_{5}-2^{\prime \prime}$ & $2.40 \mathrm{~m}$ & $2.44 \mathrm{~m}$ & $2.20 \mathrm{~m}$ & $2.46 \mathrm{~m}$ & $2.48 \mathrm{~m}$ & $2.46 \mathrm{~m}$ & $2.44 \mathrm{~m}$ & $2.47 \mathrm{~m}$ & $2.44 \mathrm{~m}$ \\
\hline $3^{\prime \prime}$ & $1.21 \mathrm{~d}(7.0)$ & $1.51 \mathrm{~m}, 1.44 \mathrm{~m}$ & $1.79 \mathrm{~m}, 1.53 \mathrm{~m}$ & $1.20 \mathrm{~d}(7.0)$ & $1.22 \mathrm{~d}(6.8)$ & $1.23 \mathrm{~d}(7.4)$ & $1.27 \mathrm{~d}(6.8)$ & $1.26 \mathrm{~d}(7.0)$ & $1.22 \mathrm{~d}(6.6)$ \\
\hline $4^{\prime \prime}$ & $1.19 \mathrm{~d}(7.0)$ & $0.96 \mathrm{t}(7.4)$ & 0.96 t (7.4) & $1.21 \mathrm{~d}(7.0)$ & $1.22 \mathrm{~d}(6.8)$ & $1.21 \mathrm{~d}(7.4)$ & $1.22 \mathrm{~d}(6.8)$ & $1.26 \mathrm{~d}(7.0)$ & $1.22 \mathrm{~d}(6.6)$ \\
\hline $5^{\prime \prime}$ & & $1.17 \mathrm{~d}(6.9)$ & $1.17 \mathrm{~d}(6.9)$ & & & & & & \\
\hline OAc-1 & $2.05 \mathrm{~s}$ & & & $2.07 \mathrm{~s}$ & $2.07 \mathrm{~s}$ & & & $2.06 \mathrm{~s}$ & \\
\hline OAc-2 & & & & $1.88 \mathrm{~s}$ & $1.87 \mathrm{~s}$ & $1.96 \mathrm{~s}$ & & & \\
\hline OAc-30 & $2.02 \mathrm{~s}$ & & $2.05 \mathrm{~s}$ & $2.02 \mathrm{~s}$ & $2.02 \mathrm{~s}$ & $2.04 \mathrm{~s}$ & $2.07 \mathrm{~s}$ & $2.04 \mathrm{~s}$ & $2.07 \mathrm{~s}$ \\
\hline
\end{tabular}


Table $4{ }^{13} \mathrm{C}$ NMR $(125 \mathrm{MHz})$ data of compounds $5-7$ and $9-14\left(\mathrm{CDCl}_{3}, \delta_{\mathrm{C}}\right.$ in ppm)

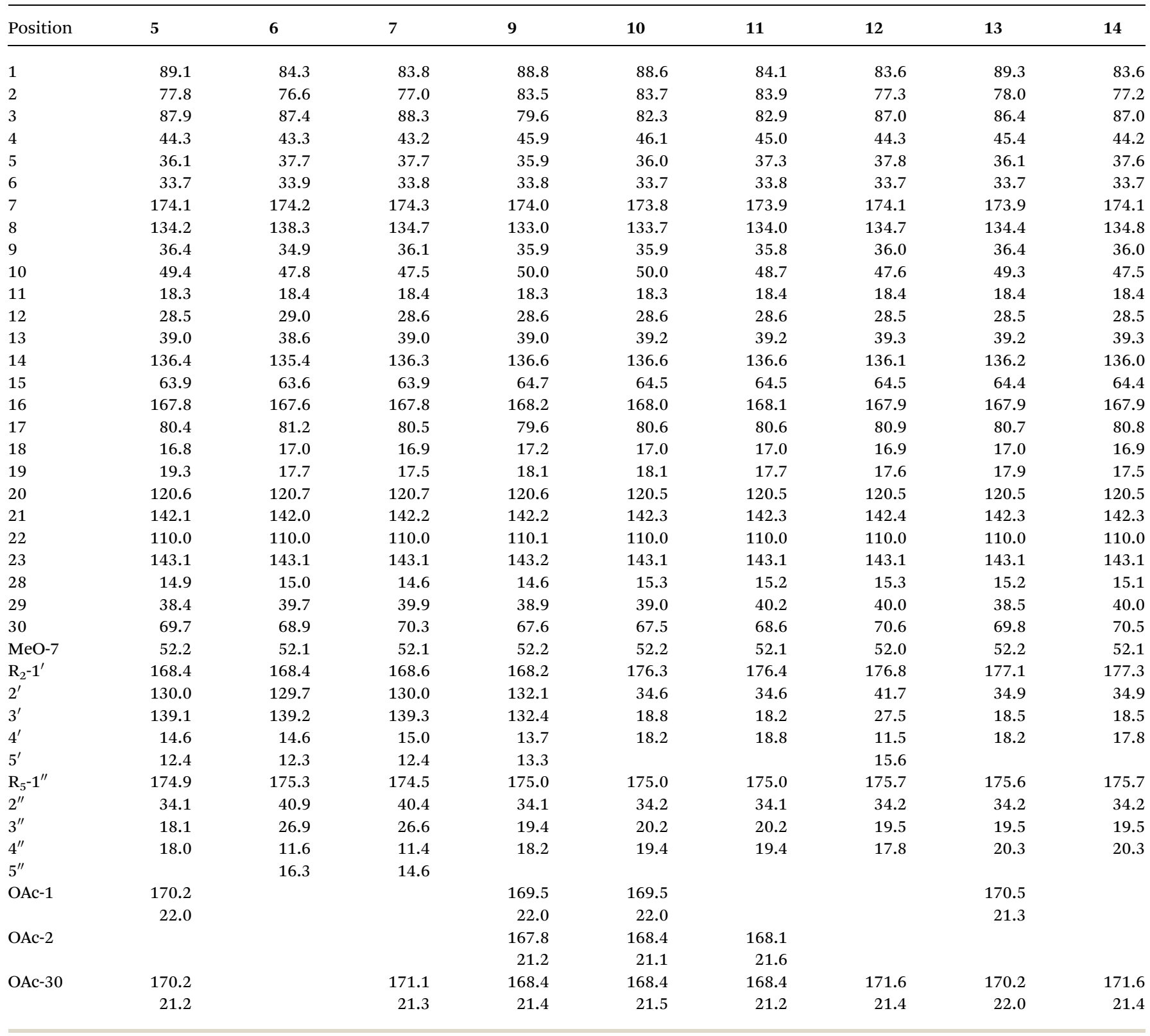

that its structure was closely related to that of trisinenmalin $\mathrm{E}$ (10), except for the absence of signals for acetoxy groups and the presence of a hydroxyl group in 11, which was consistent with the reduction of 42 amu in molecular weight, as was observed. Moreover, the chemical shift of C-1 $\left(\delta_{\mathrm{C}} 84.1\right)$ in 11 was shifted upfield $\left(\Delta \delta_{\mathrm{C}} 4.5\right)$ in comparison with that in trisinenmalin $\mathrm{E}$ (10), which further confirmed that C-1 was substituted by a hydroxy group instead of an acetoxy moiety. The relative configuration was found to be the same as that of $\mathbf{1 0}$ by an ROESY experiment (ESI Fig. S92 $\dagger$ ). Accordingly, the structure of trisinenmalin F (11) was determined, as shown in Fig. 1.

Trisinenmalin G (12) was afforded as a white, amorphous powder having a molecular formula of $\mathrm{C}_{38} \mathrm{H}_{50} \mathrm{O}_{13}$, as established on the basis of the prominent HRESIMS ion peak at $\mathrm{m} / \mathrm{z}$ $753.2890\left([\mathrm{M}+\mathrm{K}]^{+}\right.$, calcd for $\mathrm{C}_{38} \mathrm{H}_{50} \mathrm{O}_{13} \mathrm{~K}$ 753.2883). The ${ }^{1} \mathrm{H}$ and
${ }^{13} \mathrm{C}$ NMR data revealed that $\mathbf{1 2}$ was a structural congener of $\mathbf{1 1}$. Detailed analysis of the 1D and 2D NMR data indicated that the major differences between these two compounds were the substituent groups at C-2 and C-3. The hydroxy group at C-2 and the 2-methylbutanoate group at $\mathrm{C}-3$ were inferred from the corresponding HMBC correlations, respectively. On the basis of extensive analysis of all the data, compound 12, which was given the trivial name of trisinenmalin $\mathrm{G}$, was established, as shown in Fig. 1, and assigned the same relative configuration as that of $\mathbf{1 1}$ by analysis of the ROESY spectrum.

Trisinenmalin $\mathrm{H}$ (13) was isolated as a white, amorphous powder. The molecular formula of $\mathrm{C}_{39} \mathrm{H}_{50} \mathrm{O}_{14}$ was deduced from the positive prominent HRESIMS ion peak at $m / z 781.2833([\mathrm{M}+$ $\mathrm{K}]^{+}$, calcd for $\mathrm{C}_{39} \mathrm{H}_{50} \mathrm{O}_{14} \mathrm{~K} 781.2832$ ). By comparison, the ${ }^{1} \mathrm{H}$ and ${ }^{13} \mathrm{C}$ NMR data (Tables 3 and 4 ) of 13 were similar to those of 
Table 5 Cytotoxicity of compounds 1-14 against cancer cell lines

\begin{tabular}{llll}
\hline & \multicolumn{2}{l}{ Cell line, $\mathrm{IC}_{50}(\mu \mathrm{M})$} & \\
\cline { 2 - 4 } Compound & K562 & SGC-7901 & BEL-7402 \\
\hline $\mathbf{1}$ & $>40^{b}$ & $>40$ & $>40$ \\
$\mathbf{2}$ & $>40$ & $>40$ & $>40$ \\
$\mathbf{3}$ & $>40$ & $>40$ & $>40$ \\
$\mathbf{4}$ & $>40$ & $>40$ & $>40$ \\
$\mathbf{5}$ & $15.75 \pm 0.23$ & $15.54 \pm 0.27$ & $10.63 \pm 0.71$ \\
$\mathbf{6}$ & $>40$ & $>40$ & $38.57 \pm 0.86$ \\
$\mathbf{7}$ & $24.81 \pm 1.12$ & $14.56 \pm 0.46$ & $11.87 \pm 0.62$ \\
$\mathbf{8}$ & $>40$ & $>40$ & $>40$ \\
$\mathbf{9}$ & $>40$ & $>40$ & $>40$ \\
$\mathbf{1 0}$ & $>40$ & $27.99 \pm 0.90$ & $36.11 \pm 0.84$ \\
$\mathbf{1 1}$ & $>40$ & $>40$ & $37.30 \pm 0.40$ \\
$\mathbf{1 2}$ & $26.77 \pm 0.52$ & $15.22 \pm 0.78$ & $11.72 \pm 0.53$ \\
$\mathbf{1 3}$ & $>40$ & $>40$ & $27.14 \pm 0.77$ \\
$\mathbf{1 4}$ & $27.65 \pm 0.46$ & $17.15 \pm 0.29$ & $19.15 \pm 0.31$ \\
Taxol $^{a}$ & $2.07 \pm 0.17$ & $4.26 \pm 0.30$ & $6.69 \pm 0.10$
\end{tabular}

${ }^{a}$ Positive control. ${ }^{b}$ Only $\mathrm{IC}_{50}$ values of $<40 \mu \mathrm{M}$ are reported.

trisinenmalin E (10), except for the absence of signals for acetoxy groups and the presence of a hydroxy group in $\mathbf{1 3}$. This inference was confirmed by the HMBC spectrum, in which the correlations from $\mathrm{H}-3\left(\delta_{\mathrm{H}} 5.04\right)$ to $\mathrm{C}-2\left(\delta_{\mathrm{C}} 78.0\right)$ and from $\mathrm{H}-30$ $\left(\delta_{\mathrm{H}} 5.50\right)$ to $\mathrm{C}-1\left(\delta_{\mathrm{C}} 89.3\right)$ and $\mathrm{C}-2$ were observed; moreover, this conclusion was consistent with the reduction of $42 \mathrm{amu}$ in the molecular weight in comparison with that of 10. The ROESY spectrum displayed signals for the same relative configuration as that of 10. Thus, the structure of $\mathbf{1 3}$ was identified, as shown in Fig. 1.

Trisinenmalin I (14) had an adduct ion peak at $\mathrm{m} / \mathrm{z} 739.2727$ $[\mathrm{M}+\mathrm{K}]^{+}$in the HRESIMS spectrum, which was 42 amu less than that of $\mathbf{1 3}$, which indicated that $\mathbf{1 4}$ was a deacetylated derivative of 13. Moreover, the chemical shift of C-1 $\left(\delta_{\mathrm{C}} 83.6\right)$ in 14 was shifted upfield $\left(\Delta \delta_{\mathrm{C}} 5.7\right)$ in comparison with that of C-1 $\left(\delta_{\mathrm{C}} 89.3\right)$ in trisinenmalin $\mathrm{H}$ (13), which indicated that $\mathrm{C}-1$ was substituted by a hydroxy group. By extensive analysis of the 1D and 2D NMR data, the structure of $\mathbf{1 4}$ was established, as shown in Fig. 1.

Two known phragmalin-type limonoids were also isolated from the same extract. Compound $\mathbf{8}$ was identified as 15 -acetyltrichagmalin $\mathrm{C}^{11}$ on the basis of a comparison of its NMR and ESI-MS data with those of the reported compound, and compound 9 was confirmed to be trisinenmalin $\mathrm{D}^{28}$ by spectroscopic data (UV, IR, 1D and 2D NMR) and HRESIMS analysis, as well as by comparison with the literature.

Trichisintons A-D were assigned to the class of limonoids that contain the unusual bicyclo[5.2.1 $\left.1^{4,10}\right]$ decane ring system. So far, compounds with this type of skeleton have only been found in four species, namely, Trichilia connaroides, ${ }^{13,26}$ Xylocarpus granatum, X. moluccensis ${ }^{29}$ and Chisocheton ceramicus. ${ }^{30}$ Fang et $a l .{ }^{26}$ proposed a biosynthetic pathway of this type of compound, of which the direct precursors were 1,2dihydroxyphragmalin-type limonoids. However, they did not obtain any phragmalin-type limonoids during their isolation experiments. In this study, five 1,2-dihydroxyphragmalin-type limonoids $(6-8,12$, and 14) were identified, which provided a crucial factor to prove the abovementioned hypothesis of the biosynthesis of these types of compound. Accordingly, 7 and $\mathbf{1 4}$ were the direct precursors of $\mathbf{4}$ and $\mathbf{1}$, respectively, and were processed by cleavage of the carbon bond in the 1,2-diol.

In summary, 12 new and 2 known phragmalin-type limonoids were isolated from the roots of $T$. sinensis for the first time.

\section{Bioactivity evaluation}

All the isolated compounds (1-14) were tested for cytotoxicity (Table 5) and AChE inhibitory activity (Table 6). Compounds 5-7 and 10-14 displayed weak inhibitory activity against selected tumor cell lines. Compounds 2-4, 6-9 and 12-14 exhibited weak AChE inhibitory activity, with inhibition percentages ranging from $16.4 \%$ to $34.9 \%$.

\section{Experimental section}

\section{General}

Optical rotations were measured in $\mathrm{CHCl}_{3}$ with a Rudolph Autopol III polarimeter (Rudolph Research Analytical, USA) at $25{ }^{\circ} \mathrm{C}$. UV spectra were recorded using a Shimadzu UV-2550 spectrometer (Beckman, USA) and a DU800 spectrophotometer (Beckman, Brea, CA, USA). IR absorption was measured with a Nicolet 380 FT-IR instrument (Thermo, USA) using KBr pellets. 1D and 2D NMR spectra were recorded on Bruker Avance 500 NMR spectrometers (Bruker, Germany) using TMS as an internal standard. HREIMS spectra were recorded with an AutoSpecPremier spectrometer (Waters, Milford, MA, USA). HRESIMS spectra were recorded with an API QSTAR Pulsar mass spectrometer (Bruker, Germany). Column chromatography was performed with silica gel $(60-80,200-300$ mesh,

Table 6 AChE inhibitory activity of compounds 1-14 (c $50 \mu \mathrm{g} \mathrm{mL}^{-1}$ )

\begin{tabular}{llllll}
\hline Compound & Percentage inhibition (\%) & Compound & Percentage inhibition (\%) & Compound & Percentage inhibition (\%) \\
\hline $\mathbf{1}$ & $<10$ & $\mathbf{6}$ & $24.4 \pm 0.9$ & $\mathbf{1 1}$ & $<10$ \\
$\mathbf{2}$ & $10.6 \pm 0.6$ & 7 & $19.7 \pm 0.8$ & $\mathbf{1 2}$ & $17.2 \pm 1.0$ \\
$\mathbf{3}$ & $34.9 \pm 2.0$ & $\mathbf{8}$ & $21.8 \pm 1.2$ & $\mathbf{1 3}$ & $19.4 \pm 1.0$ \\
$\mathbf{4}$ & $19.5 \pm 1.0$ & $\mathbf{9}$ & $16.4 \pm 1.0$ & $\mathbf{1 4}$ & $16.9 \pm 1.2$ \\
$\mathbf{5}$ & $\mathbf{1 0}$ & & & Tacrine $^{a}$ & $68.6 \pm 0.7$ \\
${ }^{a}$ Positive control $\left(0.08 \mu \mathrm{g} \mathrm{mL}^{-1}\right)$. & & &
\end{tabular}


Qingdao Haiyang Chemical Co. Ltd., China), ODS gel (20-45 $\mu \mathrm{m}$, Fuji Silysia Chemical Co. Ltd., USA) and Sephadex LH-20 (Merck, Germany). TLC was carried out on precoated silica gel G plates (Qingdao Haiyang Chemical Co. Ltd.), and spots were detected by spraying with $5 \% \mathrm{H}_{2} \mathrm{SO}_{4}$ in EtOH followed by heating.

\section{Plant material}

Roots of Trichilia sinensis were collected from Wanning, Hainan province, People's Republic of China in November 2011. The plant was identified by Prof. Zhengfu Dai of the Institute of Tropical Bioscience and Biotechnology, Chinese Academy of Tropical Agricultural Sciences. A voucher specimen (no. 20111120) was deposited at the Institute of Tropical Bioscience and Biotechnology, Chinese Academy of Tropical Agricultural Sciences.

\section{Extraction and isolation}

Air-dried and powdered roots of Trichilia sinensis (13.2 kg) were extracted three times with 95\% EtOH at room temperature to afford a crude extract (450.0 g). The extract was then dissolved in 3.0 L water and subsequently partitioned with petroleum ether $(\mathrm{PE})(3.0 \mathrm{~L} \times 3)$, EtOAc $(3.0 \mathrm{~L} \times 3)$ and $n-\mathrm{BuOH}(3.0 \mathrm{~L} \times 3)$ to give three portions. The EtOAc portion (212.0 g) was subjected to passage over a silica gel vacuum liquid chromatograph (VLC) and eluted with gradients of PE-EtOAc (from $10: 1$ to $1: 1$ ) and $\mathrm{CHCl}_{3}-\mathrm{MeOH}$ (from $25: 1$ to $0: 1$ ) to yield ten major fractions (Fr.1-Fr.10). Fr.3 (35.0 g) was applied to a silica gel VLC and eluted with a gradient of $\mathrm{CHCl}_{3}-\mathrm{MeOH}$ (from $1: 0$ to $20: 1$ ) to give four portions (Fr.3A-Fr.3D). Fr.3A (8.0 g) was applied to silica gel with $\mathrm{CHCl}_{3}$-EtOAc (20:1 to $\left.1: 1\right)$ as the eluent to give four fractions (Fr.3A1-Fr.3A4). Fr.3A4 (1.9 g) was separated on a column of Sephadex $\mathrm{LH}-20$ by elution with $\mathrm{CHCl}_{3}-\mathrm{MeOH}$ ( $1: 1)$ to obtain Fr.3A4A (950.0 mg), which was then chromatographed on a silica gel column and eluted with $\mathrm{CHCl}_{3}-\mathrm{EtOAc}$ $(4: 1)$ to yield $8(12.0 \mathrm{mg})$ and $\mathbf{1 0}(9.8 \mathrm{mg})$. By the same purification procedures, Fr.3B (9.3 g) afforded 1 (16.0 mg) and 2 (8.0 $\mathrm{mg})$. Fr.4 (17.0 g) was chromatographed on an ODS gel column and eluted with $\mathrm{MeOH}-\mathrm{H}_{2} \mathrm{O}$ (gradient from $40: 60$ to $100: 0$ ) to give seven fractions (Fr.4A-Fr.4G). Fr.4C (1.5 g) was chromatographed on a Sephadex LH-20 column and eluted with $\mathrm{MeOH}$ to give two fractions (Fr.4C1 and Fr.4C2), and then Fr.4C1 (600.0 $\mathrm{mg}$ ) was separated on a silica gel column by elution with $\mathrm{CHCl}_{3}-$ EtOAc (15: 1) to obtain 3 (12.0 mg); Fr.4C2 yielded $14(12.0 \mathrm{mg})$. Fr.4E (700.0 mg) was applied to a silica gel column (PE-CHCl isopropyl alcohol, $7: 3: 0.1)$ to obtain two subfractions (Fr.4E1 and Fr.4E2), and then Fr.4E2 (42.5 mg) was applied to a silica gel column $\left(\mathrm{CHCl}_{3}-\mathrm{MeOH}, 150: 1\right)$ to yield $4(6.0 \mathrm{mg})$. By the same purification procedures, Fr.4F afforded 6 (6.5 mg), 7 (5.0 mg), 9 $(6.0 \mathrm{mg})$ and $12(7.0 \mathrm{mg})$. Fr.6 (30.5 g) was applied to an ODS gel column and eluted with $\mathrm{MeOH}-\mathrm{H}_{2} \mathrm{O}$ (gradient from $40: 60$ to $100: 0)$ to give seven fractions (Fr.6A-Fr.6G). Fr.6E-Fr.6G were purified on a Sephadex $\mathrm{LH}-20$ column by elution with $\mathrm{CHCl}_{3}-$ $\mathrm{MeOH}(1: 1)$ and then further separated by repeated silica gel column chromatography to afford 11 (14.0 mg), 13 (10.0 mg) and 5 (40.0 $\mathrm{mg})$, respectively.
Trichisinton A (1). White, amorphous powder; $[\alpha]_{\mathrm{D}}^{26}=+273(c$ 1.2, MeOH); UV (MeOH) $\lambda_{\text {max }}(\log \varepsilon) 239$ (2.90) nm; IR (KBr) $\nu_{\text {max }}$ 3452, 2322, 1750, 1640, 1381, 1219, $1028 \mathrm{~cm}^{-1} ;{ }^{1} \mathrm{H}$ and ${ }^{13} \mathrm{C}$ NMR data: Tables 1 and 2; HREIMS $\mathrm{m} / z$ 698.2935 [M] (calcd for $\left.\mathrm{C}_{37} \mathrm{H}_{46} \mathrm{O}_{13}, 698.2938\right)$.

Trichisinton B (2). White, amorphous powder; $[\alpha]_{\mathrm{D}}^{26}=+260(c$ 0.5, MeOH); UV (MeOH) $\lambda_{\max }(\log \varepsilon) 238$ (2.85), 229 (1.18) nm; IR $(\mathrm{KBr}) \nu_{\max } 3460,2925,1748,1632,1383,1032 \mathrm{~cm}^{-1} ;{ }^{1} \mathrm{H}$ and ${ }^{13} \mathrm{C}$ NMR data: Tables 1 and 2; HRESIMS $m / z 749.3158[\mathrm{M}+\mathrm{Na}]^{+}$ (calcd for $\mathrm{C}_{39} \mathrm{H}_{50} \mathrm{O}_{13} \mathrm{Na}, 749.3149$ ).

Trichisinton C (3). White, amorphous powder; $[\alpha]_{\mathrm{D}}^{26}=+44(c$ 2.2, MeOH); UV (MeOH) $\lambda_{\max }(\log \varepsilon) 272$ (2.50), 256 (2.43) nm; IR (KBr) $\nu_{\max } 3452,2925,1742,1638,1385 \mathrm{~cm}^{-1} ;{ }^{1} \mathrm{H}$ and ${ }^{13} \mathrm{C}$ NMR data: Tables 1 and 2; HRESIMS $m / z 749.2578[\mathrm{M}+\mathrm{K}]^{+}$(calcd for $\left.\mathrm{C}_{38} \mathrm{H}_{46} \mathrm{O}_{13} \mathrm{~K}, 749.2570\right)$.

Trichisinton D (4). White, amorphous powder; $[\alpha]_{\mathrm{D}}^{26}=+184$ (c 0.9, MeOH); UV (MeOH) $\lambda_{\max }(\log \varepsilon) 272$ (2.75), 258 (2.73) nm; IR (KBr) $\nu_{\max } 3449,2924,1748,1647,1378,1031 \mathrm{~cm}^{-1} ;{ }^{1} \mathrm{H}$ and ${ }^{13} \mathrm{C}$ NMR data: Tables 1 and 2; HRESIMS $m / z$ 763.2726 $[\mathrm{M}+\mathrm{K}]^{+}$ (calcd for $\mathrm{C}_{39} \mathrm{H}_{48} \mathrm{O}_{13} \mathrm{~K}, 763.2726$ ).

Trisinenmalin A (5). White, amorphous powder; $[\alpha]_{\mathrm{D}}^{26}=-69$ (c 0.9, MeOH); UV (MeOH) $\lambda_{\max }(\log \varepsilon) 225$ (3.82) nm; IR (KBr) $\nu_{\max } 3444,2927,1729,1634,1382,1232,1029 \mathrm{~cm}^{-1} ;{ }^{1} \mathrm{H}$ and ${ }^{13} \mathrm{C}$ NMR data: Tables 3 and 4; HRESIMS $m / z$ 777.3099 $[\mathrm{M}+\mathrm{Na}]^{+}$ (calcd for $\mathrm{C}_{40} \mathrm{H}_{50} \mathrm{O}_{14} \mathrm{Na}, 777.3098$ ).

Trisinenmalin B (6). White, amorphous powder; $[\alpha]_{\mathrm{D}}^{26}=$ -114 (c 0.7, MeOH); UV (MeOH) $\lambda_{\max }(\log \varepsilon) 272$ (2.94), 256 (2.88) nm; IR (KBr) $\nu_{\max } 3450,2925,1719,1637,1384 \mathrm{~cm}^{-1} ;{ }^{1} \mathrm{H}$ and ${ }^{13} \mathrm{C}$ NMR data: Tables 3 and 4; HRESIMS $m / z$ 707.3038 [M + $\mathrm{Na}]^{+}$(calcd for $\mathrm{C}_{37} \mathrm{H}_{48} \mathrm{O}_{12} \mathrm{Na}$, 707.3038).

Trisinenmalin $\mathbf{C}(7)$. White, amorphous powder; $[\alpha]_{\mathrm{D}}^{26}=$ -138 (c 0.65, MeOH); UV (MeOH) $\lambda_{\max }(\log \varepsilon) 272$ (2.92), 254 (2.84) nm; IR (KBr) $\nu_{\max } 3451,2924,1726,1636,1462,1382$, 1228, $1024 \mathrm{~cm}^{-1} ;{ }^{1} \mathrm{H}$ and ${ }^{13} \mathrm{C}$ NMR data: Tables 3 and 4; HRESIMS $m / z 765.2888[\mathrm{M}+\mathrm{K}]^{+}$(calcd for $\mathrm{C}_{39} \mathrm{H}_{50} \mathrm{O}_{13} \mathrm{~K}$, 765.2883).

Trisinenmalin D (9). White, amorphous powder; $[\alpha]_{\mathrm{D}}^{26}=$ -240 ( c 0.75, MeOH); UV (MeOH) $\lambda_{\max }(\log \varepsilon) 272$ (2.85), 256 (2.81) nm; IR (KBr) $\nu_{\max } 3442,2954,1744,1635,1371,1247,1038$ $\mathrm{cm}^{-1} ;{ }^{1} \mathrm{H}$ and ${ }^{13} \mathrm{C}$ NMR data: Tables 3 and 4 ; HRESIMS $\mathrm{m} / \mathrm{z}$ 819.3202 $[\mathrm{M}+\mathrm{Na}]^{+}$(calcd for $\mathrm{C}_{42} \mathrm{H}_{52} \mathrm{O}_{15} \mathrm{Na}, 819.3198$ ).

Trisinenmalin E (10). White, amorphous powder; $[\alpha]_{\mathrm{D}}^{26}=$ -100 (c 0.6, MeOH); UV (MeOH) $\lambda_{\max }(\log \varepsilon) 229$ (3.71), 218 (3.90) nm; IR (KBr) $\nu_{\max } 3460,2928,1748,1627,1250,1033$ $\mathrm{cm}^{-1} ;{ }^{1} \mathrm{H}$ and ${ }^{13} \mathrm{C}$ NMR data: Tables 3 and 4 ; HRESIMS $\mathrm{m} / \mathrm{z}$ 807.3208 $[\mathrm{M}+\mathrm{Na}]^{+}$(calcd for $\mathrm{C}_{41} \mathrm{H}_{52} \mathrm{O}_{15} \mathrm{Na}, 807.3204$ ).

Trisinenmalin F (11). White, amorphous powder; $[\alpha]_{\mathrm{D}}^{26}=$ -136 (c 1.1, MeOH); UV (MeOH) $\lambda_{\max }(\log \varepsilon) 230$ (3.84) nm; IR $(\mathrm{KBr}) \nu_{\max } 3453,2969,1747,1636,1383,1235,1027 \mathrm{~cm}^{-1} ;{ }^{1} \mathrm{H}$ and ${ }^{13} \mathrm{C}$ NMR data: Tables 3 and 4; HRESIMS $m / z$ 765.3109 [M + $\mathrm{Na}]^{+}$(calcd for $\mathrm{C}_{39} \mathrm{H}_{50} \mathrm{O}_{14} \mathrm{Na}, 765.3098$ ).

Trisinenmalin G (12). White, amorphous powder; $[\alpha]_{\mathrm{D}}^{26}=$ -113 (c 0.6, MeOH); UV (MeOH) $\lambda_{\max }(\log \varepsilon) 272$ (2.96), 252 (2.93) nm; IR (KBr) $\nu_{\max } 3450,2924,1731,1636,1460,1382$, 1228, $1022 \mathrm{~cm}^{-1}$; ${ }^{1} \mathrm{H}$ and ${ }^{13} \mathrm{C}$ NMR data: Tables 3 and 4; HRESIMS $m / z 753.2890[\mathrm{M}+\mathrm{K}]^{+}$(calcd for $\mathrm{C}_{38} \mathrm{H}_{50} \mathrm{O}_{13} \mathrm{~K}, 753.2883$ ). 
Trisinenmalin $\mathbf{H}$ (13). White, amorphous powder; $[\alpha]_{\mathrm{D}}^{26}=$ -28 (c 0.9, MeOH); UV (MeOH) $\lambda_{\max }(\log \varepsilon) 272$ (2.69), 252 (2.61) nm; IR (KBr) $\nu_{\max } 3458,2924,1745,1644,1461,1380$, 1228, $1024 \mathrm{~cm}^{-1} ;{ }^{1} \mathrm{H}$ and ${ }^{13} \mathrm{C}$ NMR data: Tables 3 and 4; HRESIMS $m / z 781.2833[\mathrm{M}+\mathrm{K}]^{+}$(calcd for $\mathrm{C}_{39} \mathrm{H}_{50} \mathrm{O}_{14} \mathrm{~K}, 781.2832$ ).

Trisinenmalin I (14). White, amorphous powder; $[\alpha]_{\mathrm{D}}^{26}=-71$ (c $0.65, \mathrm{MeOH}) ; \mathrm{UV}(\mathrm{MeOH}) \lambda_{\max }(\log \varepsilon) 272$ (2.92), 256 (2.90) nm; IR (KBr) $\nu_{\max } 3456,2924,1743,1641,1460,1379$, 1227, 1135, $1023 \mathrm{~cm}^{-1} ;{ }^{1} \mathrm{H}$ and ${ }^{13} \mathrm{C}$ NMR data: Tables 3 and 4; HRESIMS $m / z 739.2727[\mathrm{M}+\mathrm{K}]^{+}$(calcd for $\mathrm{C}_{37} \mathrm{H}_{48} \mathrm{O}_{13} \mathrm{~K}$, 739.2726).

\section{Cytotoxicity assay}

A human chronic myelogenous leukemia cell line (K562), a human gastric carcinoma cell line (SGC-7901), and a human hepatocellular carcinoma cell line (BEL-7402) were bought from the Cell Bank of the Type Culture Collection of the Chinese Academy of Sciences, Shanghai Institute of Cell Biology. An MTT assay was used to determine inhibition of the growth of K562, SGC-7901, and BEL-7402 cells in vitro, and taxol was used as a positive control. Cells were cultured in RPMI 1640 medium supplemented with $10 \%$ fetal bovine serum, $100 \mathrm{IU} \mathrm{mL}^{-1}$ penicillin, and $100 \mathrm{mg} \mathrm{mL} \mathrm{m}^{-1}$ streptomycin at $37^{\circ} \mathrm{C}$ under a $5 \%$ $\mathrm{CO}_{2}$ atmosphere with $90 \%$ humidity. Cells in the logarithmic phase were used for experiments. The specific experimental procedures were the same as those described previously. ${ }^{31}$

\section{Bioassay of AChE inhibitory activity}

The AChE inhibitory activity of these compounds was assayed by the spectrophotometric method developed by Ellman ${ }^{32}$ with slight modifications. S-Acetylthiocholine iodide, 5,5'-dithiobis(2-nitrobenzoic acid) (DNTB, Ellman's reagent) and AChE were purchased from Sigma Chemicals. The compounds were dissolved in DMSO. The reaction mixture (total $200 \mu \mathrm{L}$ ) containing phosphate buffer ( $\mathrm{pH} 8.0)$, the test compound (50 $\mu \mathrm{g}$ $\left.\mathrm{mL}^{-1}\right)$, and acetylcholinesterase $\left(0.02 \mathrm{U} \mathrm{mL}^{-1}\right)$ was incubated for $20 \mathrm{~min}\left(30^{\circ} \mathrm{C}\right)$. The reaction was initiated by the addition of $20 \mu \mathrm{L}$ DNTB $\left(2.48 \mathrm{mg} \mathrm{mL}^{-1}\right)$ and $20 \mu \mathrm{L}$ acetylthiocholine iodide $\left(1.81 \mathrm{mg} \mathrm{mL}^{-1}\right)$ for the assay of AChE inhibitory activity. The hydrolysis of acetylthiocholine was monitored at $405 \mathrm{~nm}$ for one hour. Tacrine (Sigma-Aldrich, 99\%) was used as a positive control with a final concentration of $0.08 \mu \mathrm{g} \mathrm{mL} \mathrm{m}^{-1}$, and DMSO was used as a negative control with a final concentration of $0.1 \%$. All the reactions were performed in triplicate. The percentage inhibition was calculated as follows: $\%$ inhibition = $(E-S) / E \times 100$ (where $E$ is the absorbance at $405 \mathrm{~nm}$ of the solution without the test compound and $S$ is the absorbance at $405 \mathrm{~nm}$ of the solution with the test compound). The values are expressed as the mean \pm SD of triplicate experiments.

\section{Acknowledgements}

This research was financially supported by the Special Fund for Agro-scientific Research in the Public Interest (201303117), Special Grant for Modernization of Traditional Chinese
Medicine of Hainan Province (2015ZY04), and Key Research and Development Scheme of Hainan Province (ZDYF2016140).

\section{Notes and references}

1 D. J. Newman, J. Med. Chem., 2008, 51, 2589-2599.

2 K. H. Lee, J. Nat. Prod., 2010, 73, 500-516.

3 D. J. Newman and G. M. Cragg, J. Nat. Prod., 2012, 75, 311335.

4 D. J. Newman and G. M. Cragg, J. Nat. Prod., 2016, 79(3), 629661.

5 G. Jayaprakasha, R. Singh, J. Pereira and K. Sakariah, Phytochemistry, 1997, 44, 843-846.

6 X. Fang, Y. T. Di and X. J. Hao, Curr. Org. Chem., 2011, 15, 1363-1391.

7 Q. G. Tan and X. D. Luo, Chem. Rev., 2011, 111, 7437-7522. 8 J. B. Sun, N. Jiang, M. Y. Lv, P. Wang, F. G. Xu, J. Y. Liang and W. Qu, RSC Adv., 2015, 5, 24750-24757.

9 H. P. Zhang, S. H. Wu, Y. M. Shen, Y. B. Ma, D. G. Wu, S. H. Qi and X. D. Luo, Can. J. Chem., 2003, 81, 253-257.

10 X. N. Wang, C. Q. Fan, S. Yin, L. S. Gan and J. M. Yue, Phytochemistry, 2008, 69, 1319-1327.

11 Q. Zhang, Y. T. Di, H. P. He, X. Fang, D. L. Chen, X. H. Yan, F. Zhu, T. Q. Yang, L. L. Liu and X. J. Hao, J. Nat. Prod., 2011, 74, 152-157.

12 H. Y. Wang, J. S. Wang, S. M. Shan, X. B. Wang, J. Luo, M. H. Yang and L. Y. Kong, Planta Med., 2013, 79, 17671774.

13 H. Y. Wang, J. S. Wang, Y. Zhang, J. Luo, M. H. Yang, X. B. Wang and L. Y. Kong, Chem. Pharm. Bull., 2013, 61, 1075-1080.

14 C. P. Liu, J. B. Xu, Y. S. Han, M. A. Wainberg and J. M. Yue, Org. Lett., 2014, 16, 5478-5481.

15 F. L. An, J. Luo, X. B. Wang, M. H. Yang and L. Y. Kong, Org. Biomol. Chem., 2016, 4, 1231-1235.

16 T. A. Olugbade and S. A. Adesanya, Phytochemistry, 2000, 54, 867-870.

17 I. J. C. Vieira, O. de Aquino Azevedo, J. J. de Souza, R. BrazFilho, M. dos Santos Gonçalves and M. F. de Araújo, Molecules, 2013, 18, 2589-2597.

18 A. J. Aladesanmi and S. A. Odediran, Fitoterapia, 2000, 71, 179-182.

19 M. del Carmen Ramírez, R. A. Toscano, J. Arnason, S. Omar, C. M. Cerda-García-Rojas and R. Mata, Tetrahedron, 2000, 56, 5085-5091.

20 W. W. Harding, H. Jacobs, P. A. Lewis, S. McLean and W. F. Reynolds, Nat. Prod. Lett., 2001, 15, 253-260.

21 Q. Zhang, Y. Zhang, H. P. He, Y. T. Di and X. J. Hao, Nat. Prod. Commun., 2012, 7, 1267-1268.

22 S. K. Chen, B. Y. Chen and H. Li, in Flora Republicae Popularis Sinicae (Zhongguo Zhiwu Zhi), Science Press, Beijing, 1997, vol. 34, p. 68.

23 Editorial Committee of Chinese Materia Medica; the Administration Bureau of Traditional Chinese Medicine, Chinese Materia Medica (Zhonghua Bencao), Shanghai Science \& Technology Press, Shanghai, 2000, vol. 13, pp. 3880-3881. 
24 H. F. Dai, X. L. Zheng, F. W. Xing and W. L. Mei, Records of Li Folk Medicine, China Science \& Technology Press, Beijing, 2014, vol. 3, pp. 135-136.

25 J. B. Xu, Y. Lin, S. H. Dong, F. Wang and J. M. Yue, J. Nat. Prod., 2013, 76, 1872-1880.

26 X. Fang, Y. T. Di, Z. L. Geng, C. J. Tan, J. Guo, J. Ning and X. J. Hao, Eur. J. Org. Chem., 2010, 2010, 1381-1387.

27 D. A. Mulholland, B. Parel and P. H. Coombes, Curr. Org. Chem., 2000, 4, 1011-1054.

28 W. Yang, D. M. Fang, H. P. He, X. J. Hao, Z. J. Wu and G. L. Zhang, Rapid Commun. Mass Spectrom., 2013, 27, 1203-1212.
29 J. Li, M. Y. Li, T. Bruhn, D. C. Götz, Q. Xiao, T. Satyanandamurty, J. Wu and G. Bringmann, Chem.-Eur. J., 2012, 18, 14342-14351.

30 I. A. Najmuldeen, A. H. A. Hadi, K. Awang, K. Mohamad, K. A. Ketuly, M. R. Mukhtar, S.-L. Chong, G. Chan, M. A. Nafiah, N. S. Weng, O. Shirota, T. Hosoya, A. E. Nugroho and O. Shirota, J. Nat. Prod., 2011, 74, 13131317.

31 Y. X. Li, W. L. Mei, W. J. Zuo, Y. X. Zhao, W. H. Dong and H. F. Dai, Phytochem. Lett., 2012, 5, 41-44.

32 G. L. Ellman, K. D. Courtney, A. J. Valentino and R. M. Featherstone, Biochem. Pharmacol., 1961, 7, 88-95. 